\title{
MUTAGENIC SENSITIVITY OF MATURING GERM CELLS IN THE MALE MOUSE
}

\author{
A. J. BATEMAN \\ (British Empire Cancer Campaign Research Fellow) \\ Christie Hospital and Holt Radium Institute, Manchester
}

1. INTRODUCTION

Received I.viii.57

IT had been assumed until recently that Drosophila male germ cells showed only two phases of mutational response to irradiation : postmeiotic and pre-meiotic. With successive matings of males given a single dose of radiation, the post-meiotically irradiated stages would be sampled first. These would be followed by a sterile period lasting a few days. By then, pre-meiotically irradiated stages (spermatogonia) would have matured into ripe sperm. This second phase differed from the first in a lower yield of recessive lethals and no effects attributable to chromosome breakage or rearrangement.

Lüning (1952) was the first to show that the "sterile" period was due to a high incidence of dominant lethal mutations in sperm which had been irradiated as spermatids. There has been some disagreement, however, as to the precise stage showing this hypersensitivity. Lüning (loc. cit.) and Bateman (1956a and 1957b) held that the hypersensitivity extended from meiosis to late spermatids. Auerbach (1954) and Khishin (1955), on the other hand, claimed that the hypersensitivity was confined to late spermatids.

In the mouse it has similarly been customary to regard male germ cells as showing two distinct responses to mutagens, post- and pre-meiotic, separated in sampling time, following a single dose, by a sterile period, often of two months or more according to dose. I considered that if lower doses were used, permitting fertility to continue right through this period, the sensitivity of the successive stages of spermatogenesis would be revealed.

There was already evidence that matings towards the end of the pre-sterile period showed a greater mutation rate than earlier matings (Brenneke, 1937 ; Hertwig, I938 ; Kaplan and Lyon, I953; Russell et al., r954; Auerbach and Slizynski, 1956).

\section{MATERIAL AND METHODS}

$\mathrm{F}_{1}$ animals were raised from two stocks originating from $\mathrm{Dr} \mathrm{D}$. S. Falconer of the Institute of Animal Genetics, Edinburgh, and designated by him as RCL and NF. They had both been selected for large body-size, and in the RCL line in particular this had produced large litters. The cross was made using RCL mothers. The $\mathrm{F}_{1}$ animals, besides being large and vigorous, mated readily, with few pseudopregnancies and large litters. The mean number of ova per ovulation was about 14 . 
$F_{1}$ males, about two months old, had only their hindquarters irradiated, under anæsthesia with Nembutal diluted ten times with saline and injected intraperitoneally at the rate of $0.1 \mathrm{I} \mathrm{ml}$. for every $10 \mathrm{gm}$. body-weight. The testes were kept outside the body wall by the pressure of an elastic band on the abdomen, and for accuracy of dose were kept pressed against a perspex window a fixed distance from the source. The rest of the body was shielded with $\mathrm{I} / \mathrm{ro}$ in. of lead. The radiation was from a $300 \mathrm{kV}$ machine with a filter giving a half-value layer of $2.5 \mathrm{~mm}$. of $\mathrm{Cu}$, and given at the rate of about $100 \mathrm{r} /$ minute.

Each male was mated weekly to four $F_{1}$ virgin females that were not his sisters and were examined twice daily for vaginal plugs. The females were usually dissected at 12 days for counts of corpora lutea, implantations and post-implantation losses. In one series they were dissected at Io days, when the distinction between deciduomata and live fotuses was less marked but still unambiguous, and there was a clearer distinction between deciduomata and later fotal deaths.

\section{NATURE OF DOMINANT LETHALS}

Brenneke (I937) showed that the reduced litter sizes from presterile matings were not due to a reduction in the rate of fertilisation, which was normal, but to more or less severe cytological abnormalities in the cleavage divisions of the fertilised eggs, causing early death of the embryos. This death was not always early enough to prevent the embryo from evoking the normal implantation reaction.

Though "dominant lethal" is a term which could be applied with equal justification to any mutation which caused the death of the heterozygote, it has come by usage to be reserved for very early deaths presumed to have arisen through chromosome disturbance of the kind observed by Brenneke. These would not be expected to enable the embryo to survive much beyond the fifth day, when implantation occurs.

From the references in the literature to "phagocytosis" and "resorption" of dead embryos, one might doubt the possibility of estimating, by dissection of a female, all implantations which had died up to the time of dissection, and of determining the stage reached by each embryo at death. I have found no evidence of resorption. Embryos which die at or near the time of implantation are represented by nothing more than a deciduoma (maternal tissue). At I I days the deciduoma capsularis turns brown and remains in that condition until parturition, during which time these wart-like objects can be seen scattered among the live fotuses and of a constant size and frequency, independent of the duration of gestation. A less frequent phenomenon is the death of advanced embryos which have reached a recognised stage. If death is recent, the embryo will be stunted and white. Later the fotus disintegrates into a brown mush, still enclosed in the fotal membranes, but the placenta persists in size and remains apparently fresh.

The idea of resorption may have arisen from the observation, at nearly full term, of small warts. These are not, however, in the process of being resorbed or phagocytosed : they have been in that condition since the i 2 th day. 
Dead embryos are thus classifiable into three distinct groups.

(a) Those failing to induce any implantation reaction. They will contribute to the discrepancy between the number of corpora lutea and number of implantations. This category has been abbreviated to PRE, for " pre-implantation loss".

(b) Embryos represented as deciduomata, which are similar in structure to those induced artificially by chemical or physical stimulation of pseudopregnant uteri. It follows that their presence is no proof that the embryo was alive at the time that the endometrium was stimulated. They have been loosely referred to by Russell et al. (1954) as post-implantation deaths. Following that precedent they are referred to as ED for " early post-implantation deaths".

(c) A very heterogeneous group comprising all embryos dying between implantation at 5 days and dissection, usually at I 2 days. A fotus of some kind, however decayed, is always detectable, though dissection may be needed to disclose it. The amnion is always present and also the fotal placenta which is a fresh, dark red, and appears to be unaffected by the death of the embryo. This category is designated LD, for "late death".

Russell et al. (loc. cit.), who would seem to have classified postimplantation losses into two categories equivalent to $\mathrm{ED}$ and $\mathrm{LD}$ as defined above, referred to the dividing line as death at $10 \frac{1}{2}$ days. This is presumably because what I have called ED does not show obvious necrosis until then. Normal implantations of this age have well-marked fotuses and fotal membranes, whereas ED's show nothing but a whitish scar in the cavity under the deciduoma capsularis. From this I conclude that the ED embryo has been defunct long before I $\frac{1}{2}$ days and probably since implantation began.

Dominant lethals sensu stricto would be expected to fall under categories PRE and ED but not LD. This is corroborated by the observation that the frequency of LD is the same in control and irradiated matings. Even though one might expect some dominant lethal gene mutations to kill the embryo at every stage in its development, they did not occur with detectable frequency. That is, their incidence is too low in relation to the non-genetic causes of foetal death to manifest itself in these experiments.

The number of implantations has been abbreviated to IMP, and of corpora lutea to CL.

\section{CONFUSION OF DOMINANT LETHALS WITH OTHER PHENOMENA}

It is theoretically possible that recessive lethals might contribute to PRE, ED and LD. However, they could only show in the first generation if the females were already heterozygous for them, in 
which case, the male, being of the same stock, would be equally likely to be heterozygous. The control contribution would then be large relative to any increase resulting from radiation.

In addition to dominant lethals, the class PRE will contain unfertilised eggs, infertile eggs, eggs fertilised by sperm unable to participate in cleavage (at least a theoretical possibility) and fully normal fertilised eggs which are unable to implant owing to maternal failure of the uterus to respond to the usual stimulus. There is also the possibility of copulation which was ill-timed in relation to œstrous, which might result in any of the above defects. The most extreme case of this type of failure is pseudopregnancy (abbreviated to PSP), when none of the eggs becomes implanted. This is distinguishable from complete failure of the mated female to respond to the mating (which occurs occasionally), by dissection at 12 days, when in PSP the CL formed at mating are found to have persisted as large white bodies. Dissection then coincides with the first œstrous following the mating.

I have also found in this material I 2-day uteri in which one horn is normal but the other is empty, though the ovary on that side carries the normal crop of CL. I have called this semi-PSP, as one horn has behaved in the same way as the whole uterus in PSP. In such cases the normal horn is evidence that the failure of the other cannot be due to failure of the sperm or timing of insemination, but must arise from some asymmetry of maternal function. Full PSP probably stems from a similar failure of both horns. This discussion refers to PSP and semi-PSP in control matings. Any increase in the treated series must obviously arise from other causes.

It has been amply proven that irradiation of mature sperm has no effect on its powers of fertilisation. In later weeks, however, as shown by Schaefer (I939) the rate of fertilisation is reduced owing to extreme shortage of sperm. PRE is therefore an unreliable measure of dominant lethal mutation rate. Not only are many other factors contributing to it and therefore causing a high error variation, but some of these factors are affected by the treatment itself and thus introduce something much more serious, namely, bias.

Moreover, the existence of PSP presents a special problem. They could be included as PRE, thereby greatly increasing the error variance. But their exclusion is also likely to exclude genuine cases of roo per cent. dominant lethal incidence, and thus cause underestimation of mutation rate.

$\mathrm{ED}$, on the other hand, seems to have few possible causes other than true dominant lethals. If $\mathrm{LD}$ can arise at any time during pregnancy as a result of non-genetic factors, these same factors might be expected to contribute also to ED. But since the total magnitude of LD is small, the corresponding contribution to ED is not likely to be troublesome. Maternal inadequacy in the development of the deciduoma might be expected to produce ED. A small deciduoma 
has been seen, incompletely attached to the endometrium, but it was a single instance.

Discussion of ED would be incomplete without mention that similar structures are also seen in pregnancies in which one or both parents are semi-sterile owing to heterozygosity for a translocation. The deciduomata are then supposed to be due to duplication-deficiency zygotes, whose type of chromosome unbalance is somewhat similar to that expected to result from the chromosome breaks in dominant lethal zygotes. No males showed any indication of being semi-sterile. The possibility of a contribution to $\mathrm{ED}$ from that source can be excluded.

When all implantations are of the ED type, pregnancy terminates on the I2th day, just as for PSP, though there is no confusion with PSP on dissection. The deciduomata undergo a transformation quite different from those in full-term pregnancies. There is no browning of the chorion. The whole structure rounds off and becomes detached from the endometrium as an amorphous pink lump. If the uterus is dissected after the disappearance of the deciduomata it can still be distinguished from PSP by the attachment scars along the mesometrial groove.

There is thus little ambiguity about the recognition or interpretation of ED.

Owing to the unknown and variable frequency of unfertilised ova, it has been considered best to use only post-implantation data for the estimation of mutation rate. From arguments presented elsewhere (Bateman, I958) the best estimate of mutation rate is taken as the ratio of deciduomata to other implantations, that is, $\frac{E D}{\text { IMP-ED }}$. This can exceed unity, when it signifies a mean incidence of more than one dominant lethal per sperm.

\section{RESULTS}

\section{(a) Control matings}

For each series of matings of irradiated males, one control male was mated in parallel, to detect any gross variation during the mating period due to environment or to the genetic constitution or age of successive batches of females. No such variation was found. The individual pregnancies are summarised in table $I$.

The ED frequency shows a resemblance to a binomial distribution, as would be expected if all pregnancies were from a homogeneous sample. In a few pregnancies there are indications of special factors at work. Thus there was one with 2 ED out of only 8 IMP. This is an abnormally high ratio and appears to be associated with other

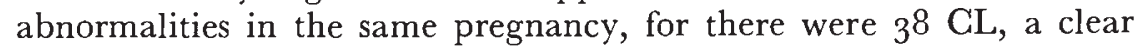
case of spontaneous superovulation, and, probably as a result of the same hormone unbalance, semi-PSP with a low IMP even in the implanted horn. The indications are that the high ED has a maternal 
cause and has no connection with mutation. There were two other pregnancies out of the total of 73 , which combined low IMP with high ED. Both had normal CL rates ( 12 and I5) but had only one IMP, which was ED.

\section{TABLE I}

(a) The combinations of $P R E$ and $E D$ found in control pregnancies. Each semi-PSP is indicated by an asterisk

\begin{tabular}{|c|c|c|c|c|c|c|c|c|c|c|c|c|c|c|c|c|c|}
\hline PRE & 0 & I & 2 & 3 & 4 & 5 & 6 & 7 & 8 & 9 & IO & I I & \multicolumn{3}{|c|}{$12-15-30-$} & $\begin{array}{c}\text { All } \\
\text { (PSP) }\end{array}$ & Total \\
\hline \multicolumn{18}{|l|}{ ED } \\
\hline o & 12 & Io & 5 & I & $\mathbf{I}$ & $2^{*}$ & $2^{*}$ & $3^{*}$ & I & & I & I * & I* & & & 6 & 46 \\
\hline I & 7 & 3 & & I & I & I & & & & I & & & I* & I $*$ & & & I 6 \\
\hline 2 & 2 & 4 & I & & & & & & & & & & \multirow{2}{*}{\multicolumn{4}{|c|}{$\mathrm{I}^{*}$}} & 8 \\
\hline 3 & I & & 2 & & & & & & & & & & & & & & 3 \\
\hline Total & 22 & I 7 & 8 & 2 & 2 & 3 & 2 & 3 & I & I & I & I & 2 & I & I & 6 & 73 \\
\hline
\end{tabular}

(b)

\begin{tabular}{|ll|rrrrrrrrrrrr|}
\hline CL per pregnancy & $\cdot$ & I0 & II & I2 & I3 & I4 & I5 & I6 & I 7 & I8 & I9 $-22-38$ \\
Number of pregnancies & $\cdot$ & 2 & 3 & 9 & I0 & I4 & I4 & 8 & 3 & 3 & 2 & I & I
\end{tabular}

TABLE 2

Summary of control data. Individual males compared

\begin{tabular}{|c|c|c|c|c|c|c|c|}
\hline Male & A & B & C & D & $\begin{array}{l}\text { A few } \\
\text { pooled }\end{array}$ & & $\begin{array}{c}\text { Grand } \\
\text { total }\end{array}$ \\
\hline \multicolumn{8}{|l|}{ Frequencies } \\
\hline CL & 263 & 346 & 326 & 162 & I I 9 & & 1216 \\
\hline IMP & 257 & 291 & 278 & I 54 & II 2 & & 1092 \\
\hline ED & I3 & 14 & 8 & 4 & 6 & & 45 \\
\hline LD & 9 & 6 & I I & 7 & 5 & & $3^{8}$ \\
\hline PSP & $2 \cdot 5$ & $6 \cdot 5$ & 4 & $2 \cdot 5$ & 0 & & 15.5 \\
\hline Matings . . & $2 \mathrm{I}$ & $3^{2}$ & 28 & I 5 & IO & & I 06 \\
\hline Percentages & & & & & & Mean & $\begin{array}{l}\text { Weighted } \\
\text { mean }\end{array}$ \\
\hline $\mathrm{PRE} / \mathrm{CL}$ & $2 \cdot 3$ & I $5 \cdot 9$ & $14 \cdot 7$ & $4 \cdot 9$ & $5 \cdot 9$ & $8 \cdot 7$ & 10.2 \\
\hline ED/IMP-ED) . & 53 & $5 \cdot I$ & 3.0 & $2 \cdot 7$ & $5 \cdot 7$ & $4 \cdot 4$ & $4 \cdot 3$ \\
\hline LD/(IMP-ED) & $3 \cdot 7$ & $2 \cdot 2$ & $4^{I}$ & 47 & $4 \cdot 7$ & 3.9 & $3 \cdot 6$ \\
\hline PSP & II 9 & $20 \cdot 3$ & 14.3 & $16 \cdot 7$ & 0.0 & I $2 \cdot 6$ & I $4 \cdot 6$ \\
\hline
\end{tabular}

On considering PRE, however, we find that even after excluding the above three semi-PSP's, as well as 6 PSP's and 5 additional semiPSP's, there still remain three pregnancies with many PRE, namely 8, 9 and io. Clearly, even after excluding grossly abnormal pregnancies, PRE is much more erratic than ED in the control series.

Examination of the control data confirms the conclusion from the earlier theoretical considerations that ED is likely to be superior to PRE for studies on the dominant lethal mutation rate. 
MUTAGENIC SENSITIVITY IN THE MOUSE

219

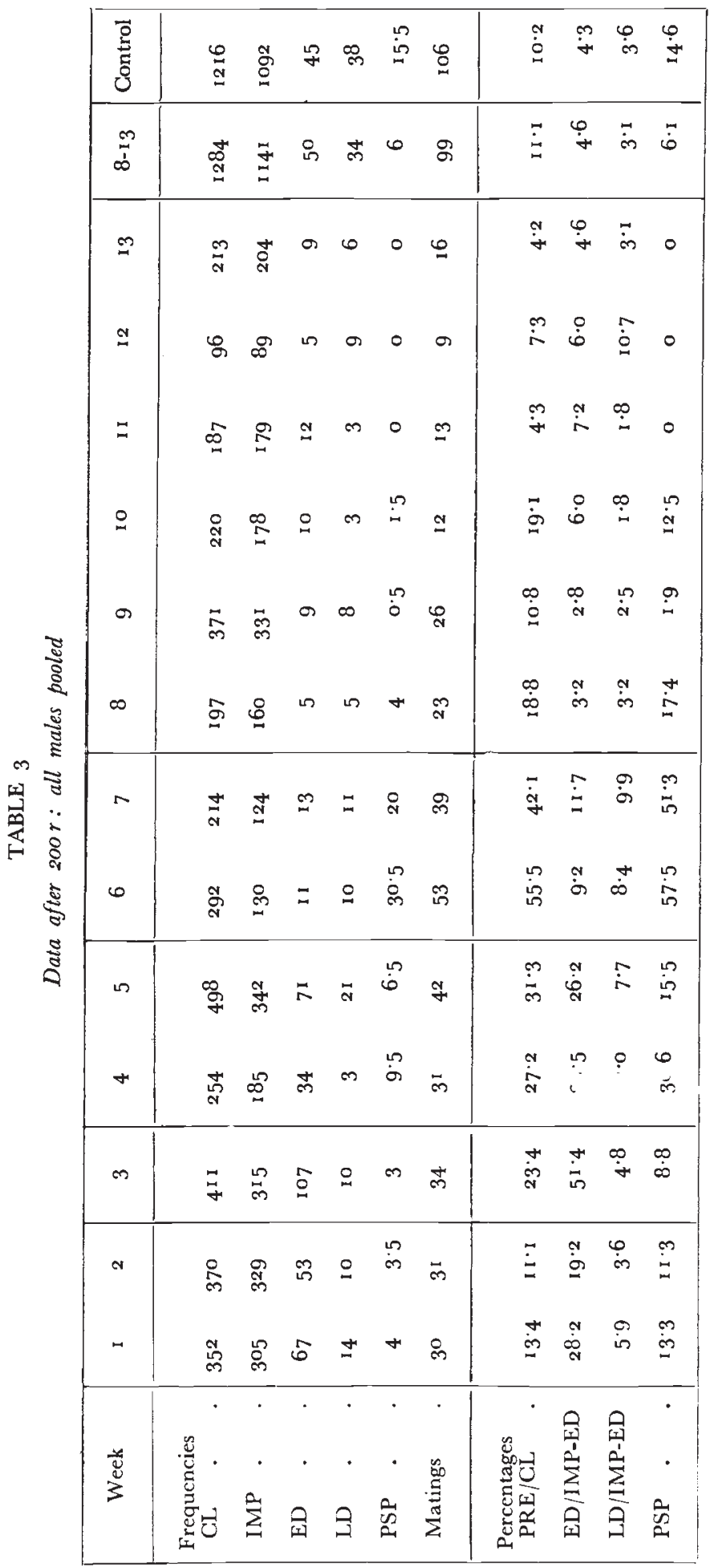


In table 2 the control data are presented in the same manner as for the irradiated series, for comparison. PRE varies between males from 2.3 to 15.9 per cent., but both ED and LD are very constant at around 4 per cent. The incidence of PSP (counting semi-PSP as $\frac{1}{2}$ ) was fairly low, at 14.6 per cent., and the mating rate (per cent. females mated after one week) 94 per cent. PSP and semi-PSP are excluded from all estimations except PSP rate and mating rate.

TABLE 4

$E D /(I M P-E D)$ as a percentage after $200 \mathrm{r}$ : individual values for each male All matings PSP shown thus : - . No matings : shown blank

\begin{tabular}{|c|c|c|c|c|c|c|c|c|c|c|c|c|c|c|c|}
\hline \multicolumn{3}{|c|}{ Week } & I & 2 & 3 & 4 & 5 & 6 & 7 & 8 & 9 & Io & II & 12 & I 3 \\
\hline $\begin{array}{l}0 \\
1 \\
2 \\
3\end{array}$ & $\cdot \quad \cdot$ & - & $\begin{array}{l}\overline{3^{8}} \\
50\end{array}$ & $\begin{array}{l}18 \\
17 \\
14\end{array}$ & $\begin{array}{l}37 \\
57\end{array}$ & $\begin{array}{l}23 \\
-\end{array}$ & $\begin{array}{l}23 \\
36\end{array}$ & IOO & $\begin{array}{r}100 \\
22\end{array}$ & $\begin{array}{l}3 \\
3\end{array}$ & $\begin{array}{l}4 \\
2\end{array}$ & & & & \\
\hline $\begin{array}{l}4 \\
5 \\
6\end{array}$ & $\begin{array}{ll}\cdot & \cdot \\
\cdot & \cdot \\
\cdot & \cdot\end{array}$ & - & $\begin{array}{l}31 \\
26 \\
24\end{array}$ & $\begin{array}{r}52 \\
8 \\
19\end{array}$ & $\begin{array}{r}40 \\
120 \\
52\end{array}$ & $\begin{array}{l}\text { 10 } \\
27 \\
33\end{array}$ & $\begin{array}{r}6 \\
35 \\
23\end{array}$ & $\begin{array}{c}- \\
9\end{array}$ & $\begin{array}{l}0 \\
2\end{array}$ & $\begin{array}{l}7 \\
0\end{array}$ & & & & & \\
\hline $\begin{array}{l}7 \\
8 \\
9\end{array}$ & 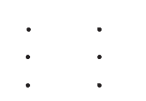 & . & $\begin{array}{l}65 \\
16 \\
14\end{array}$ & $\begin{array}{l}\text { I8 } \\
\text { IO } \\
\text { IO }\end{array}$ & $\begin{array}{l}55 \\
4^{2} \\
73\end{array}$ & $\begin{array}{r}- \\
34 \\
8\end{array}$ & $\begin{array}{l}33 \\
4^{\mathrm{I}}\end{array}$ & $\stackrel{\mathrm{o}}{-}$ & $\begin{array}{r}33 \\
0\end{array}$ & $\begin{array}{l}4 \\
4\end{array}$ & $\begin{array}{l}4 \\
0\end{array}$ & & & & \\
\hline $\left.\begin{array}{l}10 \\
11 \\
12 \\
13\end{array}\right)$ & Kept unma & tec & until & veek 5 & & & $\begin{array}{r}0 \\
17 \\
42 \\
\text { II }\end{array}$ & $\begin{array}{c}- \\
\overline{0} \\
50\end{array}$ & $\begin{array}{l}0 \\
7 \\
0 \\
0\end{array}$ & & & & & & \\
\hline $\begin{array}{l}14 \\
15 \\
16 \\
17 \\
18 \\
19\end{array}$ & Kept unma & tec & until & veek 6 & & & & $\begin{array}{r}7 \\
11 \\
0 \\
6 \\
20 \\
20\end{array}$ & & & $\begin{array}{l}2 \\
0 \\
0 \\
0 \\
8\end{array}$ & $\begin{array}{l}2 \\
6 \\
7 \\
8\end{array}$ & $\begin{array}{r}\text { II } \\
4 \\
7 \\
6\end{array}$ & $\begin{array}{r}8 \\
20 \\
0 \\
5\end{array}$ & $\begin{array}{l}8 \\
2 \\
6 \\
2\end{array}$ \\
\hline $\begin{array}{l}\text { Mea } \\
\text { Star } \\
\text { Wei } \\
\text { (fr }\end{array}$ & $\begin{array}{l}\text { In } \\
\text { idard error } \\
\text { ghted mean } \\
\text { om table 3) }\end{array}$ & . & $\begin{array}{r}33 \cdot 0 \\
6 \cdot 2 \\
28 \cdot 2\end{array}$ & $\begin{array}{r}18 \cdot 4 \\
4 \cdot 4 \\
19 \cdot 2\end{array}$ & $\begin{array}{r}59 \cdot 5 \\
9 \cdot 6 \\
5^{1 \cdot 4}\end{array}$ & $\begin{array}{r}22 \cdot 5 \\
4 \cdot 6 \\
22 \cdot 5\end{array}$ & $\begin{array}{r}24 \cdot 3 \\
4 \cdot 3 \\
26 \cdot 2\end{array}$ & $\begin{array}{r}20 \cdot 3 \\
9 \cdot 1 \\
9 \cdot 2\end{array}$ & $\begin{array}{l}16 \cdot 4 \\
\text { I0.0 } \\
\text { II } 7\end{array}$ & $\begin{array}{l}3.5 \\
0 \cdot 9 \\
3 \cdot 2\end{array}$ & $\begin{array}{l}2 \cdot 5 \\
1 \cdot 0 \\
2 \cdot 8\end{array}$ & $\begin{array}{l}5 \cdot 8 \\
1 \cdot 3 \\
6 \cdot 0\end{array}$ & $\begin{array}{l}7 \cdot 0 \\
1 \cdot 5 \\
7 \cdot 2\end{array}$ & $\begin{array}{l}8 \cdot 3 \\
4 \cdot 3 \\
6 \cdot 0\end{array}$ & $\begin{array}{l}4 \cdot 5 \\
1 \cdot 5 \\
4 \cdot 6\end{array}$ \\
\hline
\end{tabular}

The mating rate was equally high for all treatments, showing no effect of dose or mating history. No further reference need be made to it.

(b) $200 \mathrm{r}$

This dose was chosen as one high enough to give a significant mutation rate, but low enough to allow fertility to continue after week 3 , so that mutation rate could be measured over a longer period than studied hitherto. It fulfilled these expectations. The week-byweek analysis of the results is shown in table 3 for all statistics, and in 
table 4 for details of IMP and ED alone, arranged so as to show any differences between males. No such differences are evident. The results are shown graphically in figs. I and 2.

Fig. I shows that, apart from an approximate doubling in week 3, a fairly constant level of mutation is maintained for the first 7 weeks from irradiation. At week 8 the level falls abruptly to the control value and stays there indefinitely.

Fig. 2 shows important differences in the behaviour of PRE and ED. The rise in PRE for week 3, paralleling up to that point the changes in $\mathrm{ED}$, continues until week 7 . This is due to a reduction in the fertilisation rate for weeks 4 and 5 , which becomes very severe in weeks 6 and 7 (see Schaefer, 1939). This low rate of fertilisation corresponds to the complete sterility found during the same period after higher doses such as $500 \mathrm{r}$.

It will be noticed that the variation in PSP closely follows that in PRE. It is presumably due to the same cause, namely low rate of fertilisation. There seems to be a marked difference here between my own data and Schaefer's (loc. cit.), which was obtained at the same dose. In her data, the period of greatest sterility coincided with a low mating rate, instead of a high PSP rate. Perhaps in her mice, but not in mine, the urge to mate was conditioned by the amount of sperm in the vas deferens.

Obviously, quite different interpretations of sensitivity to the induction of dominant lethals would be made according to whether one followed implantations alone, or PRE. If one followed both simultaneously (as did Russell et al., 1954) the big increase in PRE over weeks 4 to 7 would swamp the slight drop in ED. As already stated, the author bases his interpretation on ED and IMP alone. On this basis week 3 is hypersensitive to the induction of mutations and the rest of the first seven weeks are about equally sensitive at about half the level of week 3. No induced mutations are recovered after week 7 .

A day-by-day breakdown of the data for ED (table 5 and fig. 3) shows that the high value for the third week is not due to an acute phase of short duration, but extends at a constant level throughout the week. On the other hand the slightly raised value for the first week is seen to be due to increased sensitivity for the very first matings in that week. This initial high value of short duration was also found with the data at 125 and $500 \mathrm{r}$ (table 5 ).

A word is necessary on the LD incidence (see table 3) which showed a slight rise over weeks 5,6 and 7 . This might be related to the low IMP. There are grounds for expecting a connection. It has been found that when there is only one implant, the CL at I 2 days are paler than usual on the side bearing the fotus and white (as in PSP) on the other side. Apparently the stimulus from a single foetus is not sufficient to promote normal functioning of CL. One might expect uterine function to suffer in consequence. Analysis of the 


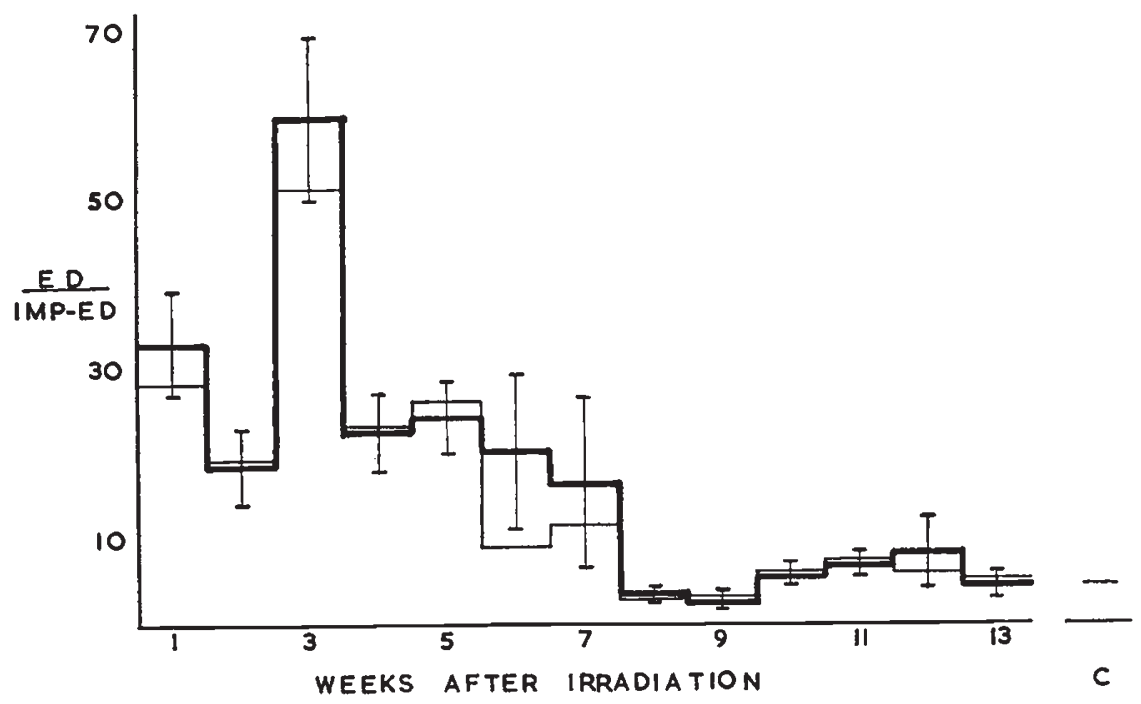

FIG. I.-Variation of $\frac{E D}{I M P-E D}$, expressed as a percentage, with successive weeks from the irradiation of the testes of mated males with $200 \mathrm{r}$. $\frac{\text { ED }}{\text { IMP-ED }}$ is the ratio of deciduomata to other implants and is taken as the best measure of dominant lethal mutation rate. Heavy line : weekly mean of values for individual males, with the standard error indicated by the vertical lines. Thin line : weighted mean from pooling data of all males. $\mathrm{C}$ : the control value.

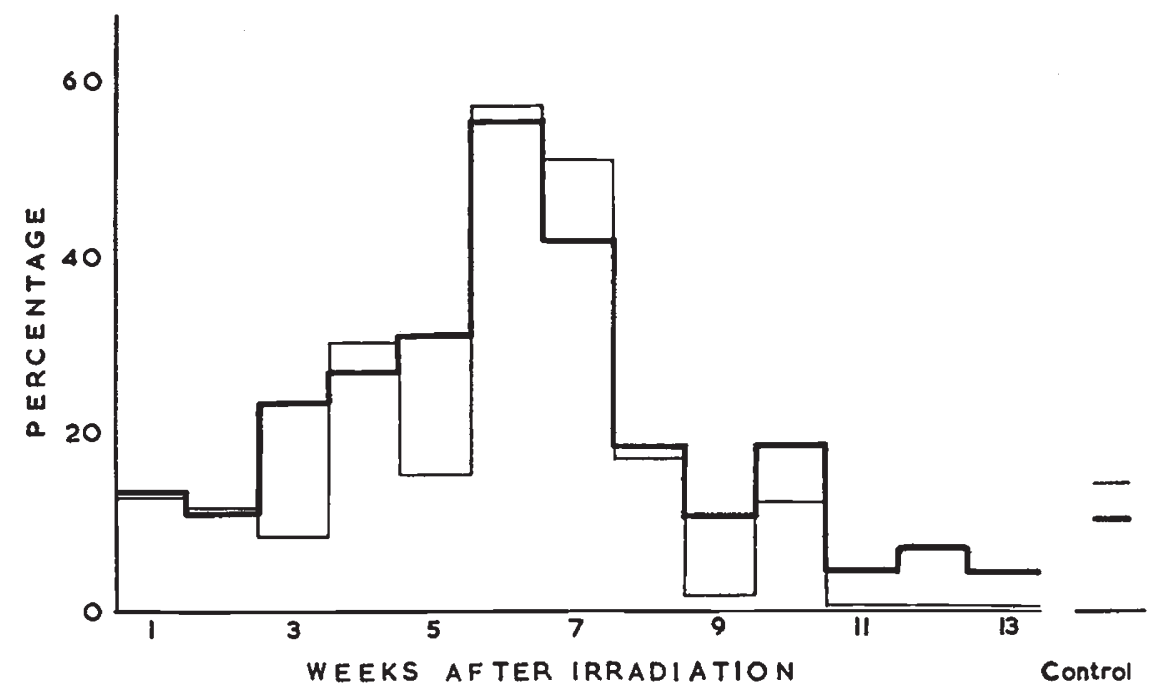

FIG. 2.-Percentage of ova failing to implant in fertile matings (pre-implantation loss = PRE : heavy line) and percentage of sterile matings (pseudopregnancy = PSP : thin line) with successive weeks from irradiation of the testes of mated males with $200 \mathrm{r}$. Control values for both parameters shown at extreme right.. 


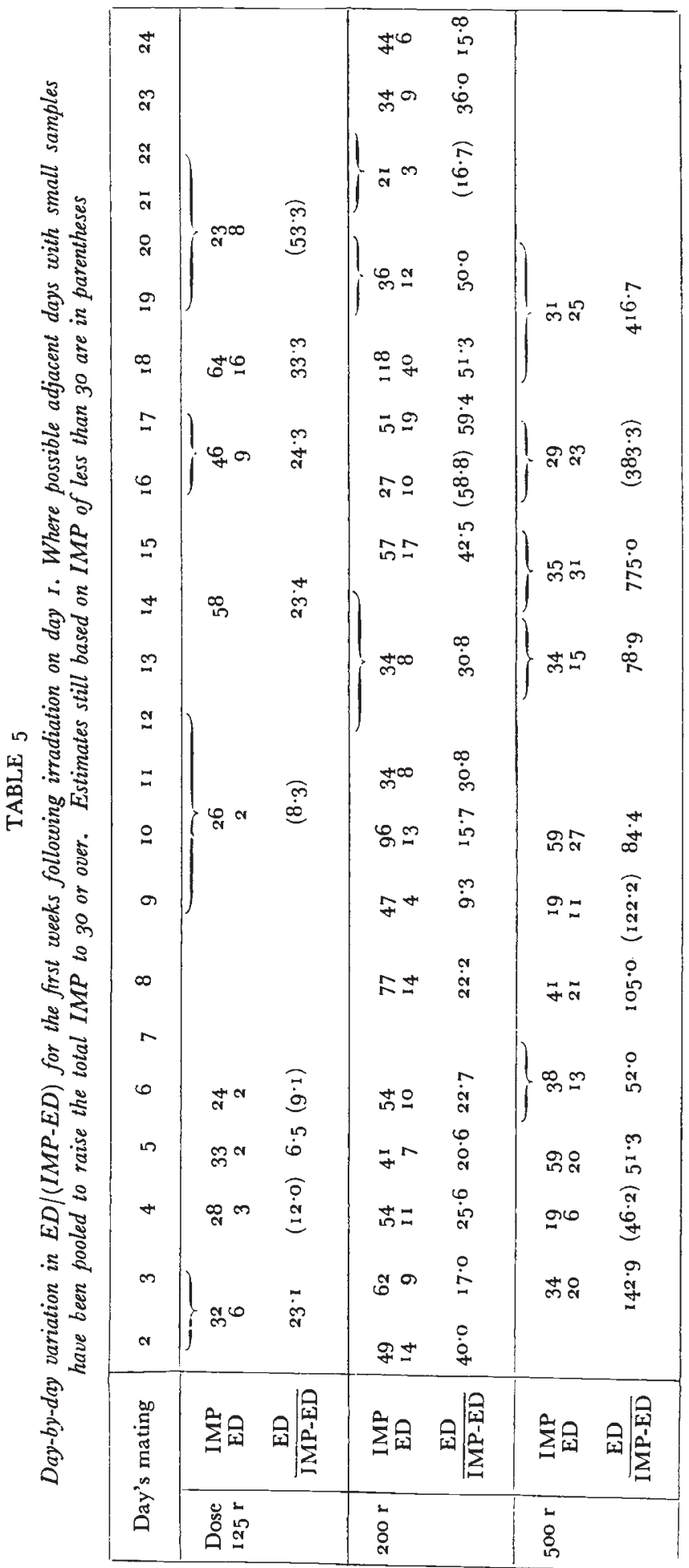


pregnancies during this period failed, however, to reveal any correlation between the number of fotuses per pregnancy and LD.

It may be that during these weeks there is a real increase in the incidence of true dominant lethal gene mutations. In that case the sensitivity pattern of the spermatogenic stages is different for chromosome breakage and gene mutation. However, the actual increase in LD is too low in comparison with the control level for it to warrant further consideration.

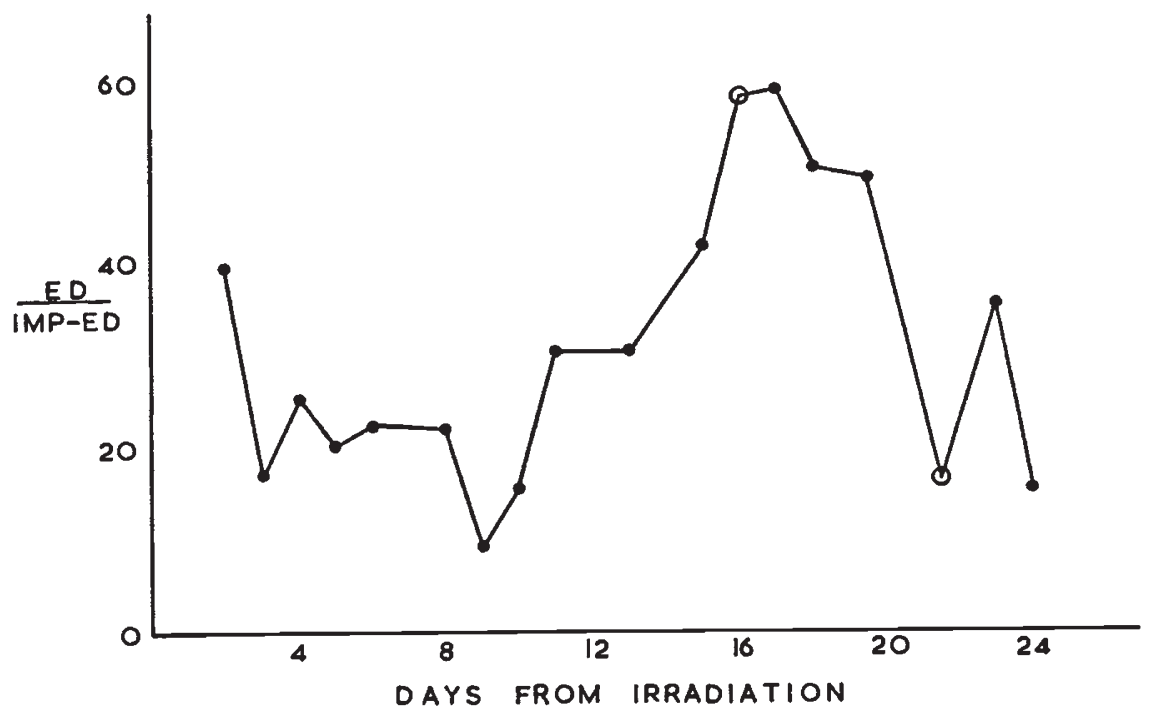

FIG. 3.-Daily values for $\frac{E D}{I M P-E D}$ following $200 \mathrm{r}$. All values based on from 30 to 118 implantations except those with the open circle which have 27 and 21 respectively.

\section{(c) $500 r$}

Matings following this dose confirmed the hypersensitivity of the third week after irradiation (table 6). This immediately preceded the prolonged sterility which lasted until the $13^{\text {th }}$ week in a few males kept with females for that length of time.

Reduced but still considerable amounts of motile and apparently healthy sperm can be recovered from the vas deferens in weeks 4 and 5 after $500 \mathrm{r}$. Sterility during this period is evidently not due to the absence of sperm but to its failure to function properly in fertilisation. Neither is it due to roo per cent. incidence of dominant lethals, for matings of males given $2000 \mathrm{r}$ were sterile at once, but dissection of the females showed plenty of IMP all of which were ED, which is quite different from the PSP without any IMP found subsequent to the third week after $500 \mathrm{r}$.

Males given this dose were also used to investigate the possible influence of mating history in determining the mutation rate in sperm samples a given time after treatment. There are several references 
to this possibility in the literature, and such an interaction has been found in Drosophila (Bateman, I956a).

The results showed no such effect. Males first mated in week 3 showed the same high mutation rate as concurrent matings of males

TABLE 6

Weekly samples after (a) $500 r$ and (b) $125 r$

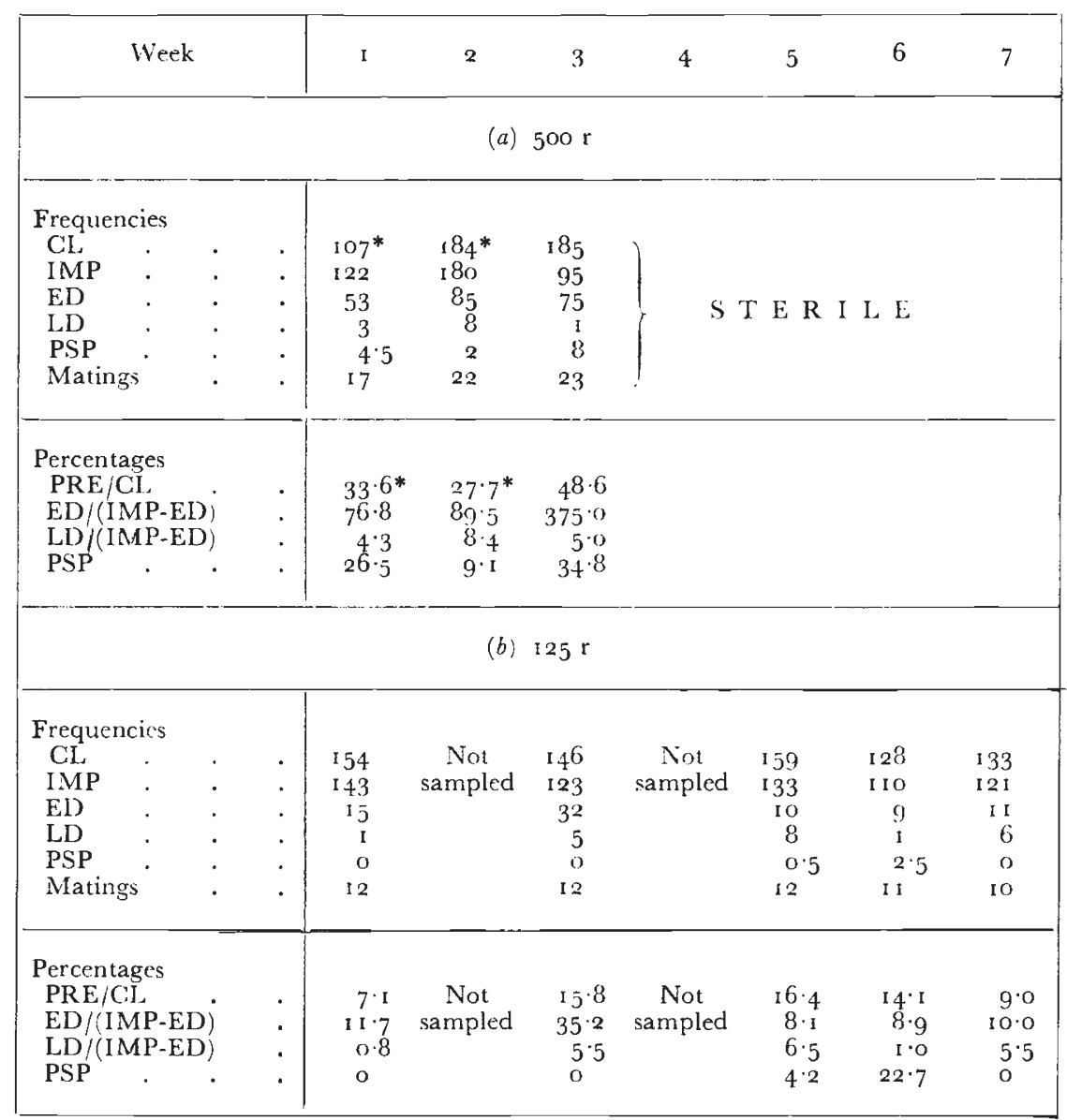

* CL, and consequently PRE:CL also, for only part of the data.

continuously mated since irradiation. Both series went sterile in week 4. Also, males first mated after week 3 were sterile at once.

It is concluded that there is no storage of sperm in the mouse. This accords with the fact that (unlike Drosophila) the male mouse has no organ for the storage of sperm. The "vesiculæ seminales" (better called "albuminiferous glands") merely secrete the material for the vaginal plug. As spermatogenesis is normally a continuous process, it would be sufficient that the newly formed sperm entering the caput epididymis should push out a continuous stream of ripe 
sperm from the distal end of the vas deferens, which would be available for any mating which might occur.

This situation greatly simplifies the interpretation of the data. Mating history can be ignored, the sole factor determining the stage at treatment of a given sperm batch being the intervening period of time.

A corollary of this type of sperm flow is that when the pressure from the oncoming sperm is removed, the sperm of previous batches will linger in the vas deferens. It is likely, therefore, that in weeks 6 and 7 after $200 \mathrm{r}$ and $125 \mathrm{r}$ (see below) sperm utilised will have matured the previous week.

\section{(d) $125 r$}

Some doubt in the interpretation of the $200 \mathrm{r}$ data arises from the high error variation in weeks 6 and 7 , owing to the high sterility and therefore small size of sample. A lower dose ( $125 \mathrm{r}$ ) was therefore chosen, sufficient to give a detectable mutation rate, but showing no sterility in weeks 6 and 7 . As will be seen from table 6 , after the expected peak in week 3 , a constant mutation rate, approximately equal to that in week $\mathrm{I}$, extended over weeks 5,6 and 7 .

\section{SPERM SAMPLE EQUATED TO STAGE IRRADIATED}

The variation in mutation rate with time of sampling is quite clear. Its interpretation in terms of the stages of spermatogenesis irradiated is more problematical. Fortunately there has recently been a number of investigations on the timing of the various stages of spermatogenesis (Leblond and Clermont, I952; Sirlin and Edwards, I 955, and Oakberg, I957). These have been synthesised into a single scheme by Sirlin and Edwards (1957).

Oakberg (I955) has shown that the later cell generations of spermatogonia are much the most sensitive to killing by irradiation : only 2 per cent. survive roo r. It is reasonable to suppose, therefore, that the high sterility of weeks 6 and 7 after $200 \mathrm{r}$ is due to the annihilation of spermatogonia. The fortnight of weeks 4 and 5 would then be sampling the products of irradiated spermatocytes, which are known from histological observation to persist for a fortnight after irradiation (i.e. spermatocytes have a life of $\mathrm{I} 4$ days). These assumptions fit the time sequence shown in fig. 4 and derived from Sirlin and Edwards (1957).

This timetable is based on the following data :-

I. Oakberg's ( I 957) estimate of 34.5 days for the complete spermatogenic cycle from stem cell to the liberation of morphologically mature sperm from the seminiferous tubules. This was partitioned between the stages as follows : spermatogonial mitoses, 6 days ; spermatocytes, I4 days; spermatids, 9 days; and sperm 5.5 days. The dividing line between spermatids and sperm is more arbitrary than the others 
as metamorphosis is continuous, without a nuclear division to mark the transition.

2. Sirlin and Edwards' (1955) observation of 8 days from the last DNA synthesis to the appearance of labelled DNA in spermatids, and a further 22 days to its appearance in the ejaculate.*

\begin{tabular}{|c|c|c|c|c|}
\hline \multirow{2}{*}{$\begin{array}{l}\text { Week } \\
\text { after } \\
\text { irradiation }\end{array}$} & \multicolumn{2}{|c|}{$\begin{array}{l}\text { Incidence of mutation and } \\
\text { sterility after }\end{array}$} & \multirow{2}{*}{\multicolumn{2}{|c|}{$\begin{array}{l}\text { Stage at which sampled sperm } \\
\text { was irradiated }\end{array}$}} \\
\hline & $200 \mathrm{r}$ & $500 \mathrm{r}$ & & \\
\hline \multirow{2}{*}{1} & \multicolumn{2}{|c|}{ High } & \multirow{3}{*}{ SPERMATOzOA in } & VAS DEFERENS \\
\hline & \multirow{2}{*}{\multicolumn{2}{|c|}{ Low }} & & EPIDIDYMIS \\
\hline 2 & & & & Testis \\
\hline 3 & \multicolumn{2}{|c|}{$\mathrm{HIGH}$} & \multicolumn{2}{|l|}{ Spermatids } \\
\hline & \multirow[b]{2}{*}{ Low } & \multirow{5}{*}{ SteriLE } & & MeIosis \\
\hline 5 & & & \multicolumn{2}{|c|}{$\begin{array}{l}\text { Spermatocytes } \\
\text { LAst DNA Synthesis }\end{array}$} \\
\hline 6 & \multirow{2}{*}{$\begin{array}{l}\text { Low } \\
\text { (with low } \\
\text { fertility) }\end{array}$} & & \multirow{2}{*}{\multicolumn{2}{|c|}{ Spermatogonia $\quad 5$ Mitoses }} \\
\hline 7 & & & & \\
\hline 8 to 13 & \multirow{2}{*}{\multicolumn{2}{|c|}{$\begin{array}{l}\text { NONE } \\
\text { with } \\
\text { full fertility }\end{array}$}} & \multirow{2}{*}{\multicolumn{2}{|c|}{ Stem Cells }} \\
\hline $14+$ & & & & \\
\hline
\end{tabular}

FIG. 4.-An attempt to equate the sequence of matings following irradiation, in respect of dominant lethal mutations and fertility, with the known spermatogenic timetable.

3. By combining these independent sets of data we can calculate that the last DNA synthesis occurs in 6-day-old spermatocytes, and that the time taken for the sperm to travel from the testis to the ejaculate is $7 \cdot 5$ days $(22-(9+5 \cdot 5))$.

It is remarkable that Schaefer (I939) had postulated, largely intuitively, the same time scale for the interpretation of her $200 \mathrm{r}$ data.

One concludes from fig. 4 that while, after $200 \mathrm{r}$ or $125 \mathrm{r}$, spermatocytes are capable of producing fully functional sperm, they do not do so after $500 \mathrm{r}$.

* There is frequent confusion over terminology in the literature, early or " resting", spermatocytes being referred to as spermatogonia type B ("crusty"). Thus these authors refer the last DNA synthesis to the spermatogonia, though it must occur in meiotic prophase, just prior to pachytene, when the spermatocyte becomes " tetraploid ". 
The statement of Auerbach (1957) that $500 \mathrm{r}$ kills spermatocytes is wrong. They persist, in diminishing numbers, as those passing out via meiosis are not replenished from the non-existent spermatogonia type B, for a fortnight, by which time they have all produced spermatids. $500 \mathrm{r}$ does not even kill all the products of division of these spermatocytes. Whilst many obviously abnormal spermatids are produced by such spermatocytes, a large number appear to be normal and metamorphose into normal-looking sperm, which can be found, alive and motile though in distinctly subnormal frequency, in the vas deferens of a male who has been mated continuously for five weeks after irradiation, though he is now quite sterile.

It would appear then that sperm from spermatocytes which have received $500 \mathrm{r}$ is incapacitated in some subtle way.

$200 \mathrm{r}$ does not appear to have this effect, though irradiated spermatocytes still produce many abnormal spermatids and malformed and necrotic sperm. The reduced rate of fertilisation in weeks 4 and 5 may be due to the incapacity of some of the sperm induced at the lower doses by the same mechanism as operates after $500 \mathrm{r}$. It is likely that in weeks 6 and 7 after the lower doses the sperm utilised is still that which was irradiated as spermatocytes (see earlier discussion).

This leads to the conclusion that irradiated meiosis is sampled as sperm at the end of the third week, though it is too short-lived a stage to be individually identifiable. The week-long hypersensitive period is, therefore, due to irradiation of spermatids at all stages from their origin to a stage where they become morphologically similar to sperm (Leblond and Clermont's "maturation stage"). This is about midway between meiosis and the liberation of the sperm from the tubules. For the rest of the time spent in the testis, and during the passage down the epididymis there is no change in sensitivity, though there is a final peak in sensitivity just before ejaculation which can probably be referred to sperm in the vas deferens.

The data here presented confirm the hypersensitivity found in the third week from irradiation by Kaplan and Lyon (1953), Russell et al. (1954) and Auerbach and Slizynski (1956). It should not be confused, however, with the increase in mutation rate found in the second week by Snell (1933), Brenneke (1937) and Hertwig (1938). A feature common to these workers was the high dosage level (80o r) which produced sterility in the third week, a sterility in all probability due to soo per cent. incidence of dominant lethals and therefore quite distinct from that in the fourth week after $500 \mathrm{r}$.

\section{PRODUCTS OF IRRADIATED SPERMATOCYTES}

I had earlier $(1956 b, c)$ fallen into the error of assuming that " dominant lethals" (i.e. chromosome breaks) induced in spermatocytes, which would be expected to result in aneuploid spermatids, would make the sperm inviable and so unable to be recovered from 
fertilised eggs. This assumption is, of course, in direct contradiction to the interpretation of semi-sterility as due to the death of duplicationdeficiency zygotes, which could only be produced from viable duplication-deficiency gametes. If the unbalanced sperm were non-functional (this theoretical possibility was pointed out by Koller in 1944, especially when the interchanged segments are large), males heterozygous for the translocation would cease to be semi-sterile, for although half the sperm would be inviable, there would still be the other half to fertilise all the eggs, and all the zygotes would then be viable.

Many effects of radiation on spermatocytes, however, such as bridges at first or second division, causing restitution, are equivalent to dominant lethals in mode of origin and will produce inviable sperm, which can be seen in irradiated testes. Consequently, sperm sampled in weeks 4 to 7 after $125 \mathrm{r}$ and $200 \mathrm{r}$ is not a complete sample of irradiated spermatocytes. It is likely to show less than the primary incidence of dominant lethals. The sensitivity of spermatocytes to mutagenesis is likely to be a minimal one when measured by dominant lethals.

There is evidence (Sparrow, I95I) that the pollen mother cells of plants are much more sensitive to chromosome breakage than other stages. If this is a property of meiotic chromosomes as such, it is likely to apply equally in plants and animals. A true measure of the mutagenic sensitivity of spermatocytes will only be found using mutations which are not, like dominant lethals, subject to germinal selection.

\section{THE STERILE PERIOD}

Although the later spermatogonial generations are destroyed by $200 \mathrm{r}$ full fertility is restored by week 8 and maintained at least until week I3. This raises the problem of how to explain the prolonged sterile period after doses such as $500 \mathrm{r}$. If there are any stem cells left alive at all, one would expect, from the spermatogenic timetable of Oakberg, that they would yield viable sperm after 40 days ( 6 weeks), whereas in fact one has to wait yet another 6 weeks for the return of fertility. Why is this?

Oakberg (1955) found that after $600 \mathrm{r}$ the surviving stem cells did not begin to repopulate the seminal epithelium until more than a week had elapsed, and it was three weeks before spermatogonia type $B$ reappeared in quantity. Evidently the spermatogenic cycle does not start up at normal speed immediately after irradiation. Even after the establishment of the spermatogonial population spermatogenesis must be retarded, to account for the further ro-week delay to the restoration of fertility.

Thus, whilst the rate of spermatogenesis of the post-spermatogonial stages is little affected by radiation, the rate of subsequent recovery of the spermatogenic cycle is greatly retarded by high doses $(500 \mathrm{r}$ and above). 
This retardation is all the more striking if one considers that in males of the same $F_{1}$ strain, full fertility is attained at an age of 6 weeks, only 9 weeks from conception, during which time not only spermatogenesis is completed but also the entire ontogeny of the genitalia.

An extreme form of the same phenomenon may account for reports that even longer periods, measured in years, are required for the restoration of fertility to men given temporarily sterilising doses of X-rays (Glucksmann, 1947).

\section{COMPARISON WITH DROSOPHILA}

According to the above interpretation of the mouse data and my own Drosophila results (1956a, 1957b), both organisms show a hypersensitive stage immediately following meiosis and extending to the transformation of the spermatids into sperm. There is a quantitative difference, however, for the ratio of sensitivity of spermatids to sperm is Io in Drosophila but only 2 in the mouse. This may be related to the much greater attenuation of the sperm head in Drosophila, the ratio of sensitivity being determined by the degree of change involved in the transformation.

It is not surprising that the products of irradiated spermatocytes have never been recognised in Drosophila, for in the adult they are a very short-lived stage. No comparison can be made, therefore, between the sensitivities of this stage for the two organisms.

There does seem to be a difference in the sensitivity of spermatogonia to the direct lethal effect of X-rays, for there is no evidence in Drosophila of the destruction of this stage by doses less than those required for roo per cent. incidence of dominant lethals in mature sperm. After $3000 \mathrm{r}$ fertility is normal from the ninth day (Bateman, r $956 a$ ). Whether there is a corresponding difference in sensitivity to induction of mutations is an open question.

\section{SUMMARY}

I. Males with a testis dose of $200 \mathrm{r}$ were mated to four virgin females per week for up to 13 weeks from irradiation, and the females dissected at 12 days.

(a) Pre-implantation losses and pseudopregnancies rise from week 2 to weeks 6 and 7 , and then fall abruptly to the control level for the rest of the period studied. The cause is partly the shortage of sperm for weeks $4-7$ which is particularly acute for weeks 6 and 7 .

(b) Deciduomata, on the other hand, show a peak incidence extending over the whole of week 3 , with about half this level both before and after up to week 8 , when the incidence falls to the control level. There is also a peak at the beginning of week $\mathrm{I}$.

(c) Fœtal deaths are at the control level throughout. 
2. The $200 \mathrm{r}$ data are confirmed by doses at I25, 500 and $2000 \mathrm{r}$.

3. The unmated male mouse does not store sperm. Consequently, mating history has no effect on the mutation rate recovered a given interval from irradiation.

4. The dominant lethal mutation rate has been estimated as the ratio of deciduomata to other implants.

5. Estimated mutation rates were :

(a) for controls and for more than 7 weeks from irradiation; $0 \cdot 04$.

(b) for the first seven weeks from irradiation (except week 3) 0.12 for $125 \mathrm{r}$; 0.28 for $200 \mathrm{r}$; and 0.77 for $500 \mathrm{r}$.

(c) for week $3: 0.35$ for I $25 \mathrm{r}$; $0.5 \mathrm{I}$ for $200 \mathrm{r}$; and 3.75 for $500 \mathrm{r}$.

6. The various sampling periods after $200 \mathrm{r}$ and $125 \mathrm{r}$ have been identified with the products of the following irradiated stages :

\begin{tabular}{|c|c|c|c|}
\hline \multirow{2}{*}{ Period } & \multirow{2}{*}{$\begin{array}{l}\text { Stage } \\
\text { irradiated }\end{array}$} & \multicolumn{2}{|c|}{ Sensitivity } \\
\hline & & Mutagenic & Other \\
\hline $\begin{array}{l}\text { Beginning of } \\
\text { week } I\end{array}$ & $\begin{array}{l}\text { Sperm in vas } \\
\text { deferens }\end{array}$ & Higlı & Nil \\
\hline $\begin{array}{l}\text { Rest of week I } \\
\text { and week } 2\end{array}$ & $\begin{array}{l}\text { Sperm, first in } \\
\text { epididymis, } \\
\text { later in testis }\end{array}$ & Standard & Nil \\
\hline Week 3 & Spermatids & Doubled & Nil \\
\hline Weeks 4 and 5 & Spermatocytes & $\begin{array}{l}\text { Minimal estimate } \\
\text { equal to standard }\end{array}$ & $\begin{array}{l}\text { No immediate effect but } \\
\text { resulting sperm partially } \\
\text { incapacitated }\end{array}$ \\
\hline Wecks 6 and 7 & Spermatogonia & No estimate possible & $\begin{array}{l}\text { Completely destroyed. The } \\
\text { sample during this period } \\
\text { consists of residuum from } \\
\text { spermatocytes }\end{array}$ \\
\hline $\begin{array}{l}\text { Weeks } 8 \text { and } \\
\text { later }\end{array}$ & Stem cells & $\begin{array}{l}\text { No dominant lethals } \\
\text { recoverable }\end{array}$ & Fairly resistant \\
\hline
\end{tabular}

7. The prolonged sterile period after $500 \mathrm{r}$ is due to the following successive factors: complete impotence of sperm in weeks 4 and 5 ; destruction of spermatogonia in weeks 6 and 7 ; retardation of the recovery of normal spermatogenic cycle for a further 6 weeks or so.

8. In both Drosophila and mouse the hypersensitive stage is the spermatid, though the relative sensitivity is 5 times greater in Drosophila.

Acknowledgment.-Thanks are due tơ Miss Veronica Baccas for technical assistance. 


\section{REFERENCES}

AUERBACH, C. 1954. Sensitivity of the Drosophila testis to the mutagenic action of $\mathrm{X}$-rays. Z.I.A.V., 86, I1 $3-125$.

AUERBACH, c. 1957. Sensitivity of immature mouse sperm to the mutagenic effects of X-rays. Nature, 179,725 .

AUERBACH, C., AND SLIZYNSKI, B. M. 1956. Sensitivity of the mouse testis to the mutagenic action of X-rays. Nature, $177,376-377$.

bateman, A.'J. I956a. Mutagenic sensitivity of maturing Drosophila sperm. I. Dominant lethals. 7. Genet., 54, 400-4 ro.

bateman, A. J. $1956 b$. Sensitivity of the mouse testis to the mutagenic action of X-rays. Nature, 177,934 .

bateman, A. J. $1956 c$ and $1957 a$. Sensitivity of immature mouse sperm to the mutagenic effects of X-rays. Nature, $178,1278-1280$ and $179,727$.

Bateman, A. J. 1957b. Mutagenic sensitivity of maturing Drosophila sperm. II. Deleted X. 7. Genet. (in the press).

BATEMAN, A. J. 1958. The partition of dominant lethals in the mouse between unimplanted eggs and deciduomata. Heredity (in the press).

BRENNEKE, H. 1937. Strahlungschädigung von Mäuse- und Rattensperma, beobachtet an der Frühentwicklung der Eier. Strahlentherapie, 6o, 214-238.

GLUCKSMANN, A. I947. The effects of radiation on reproductive organs. Brit. $\mathcal{F}$. Radiol., Suppl. 1, 101-108.

HERTWig, P. 1938. Unterscheide in der Entwicklungsfähigkeit von $F_{1}$ Mäusen nach Röntgen-bestrahlung von Spermatogonien, fertigen und unfertigen Spermatozoen. Biol. Zentr., 58, 273-301.

KAPLAN, W. D., AND LYON, M. F. 1953. Failure of mercaptoethylamine to protect against the mutagenic effects of radiation. II. Experiments with mice. Science, $118,777-778$.

KHishin, A. F. E. 1955. The response of the immature testis of Drosophila to the mutagenic action of X-rays. Z.I.A.V., 87, 97-112.

KOller, P. C. 1944. Segmental interchange in mice. Genetics, 29, 247-263.

LEBLOND, C. P., AND CLERMONT, Y. 1952. Spermiogenesis of rat, mouse, hamster and guinea-pig as revealed by the "periodic acid-fuchsin sulfurous acid" technique. Amer. 7. Anat., go, 167-2 16.

LÜNING, K. G. 1952. X-ray induced dominant lethals in different stages of spermatogenesis in Drosophila. Hereditas, $38,91-107$.

OAKBERG, E. F. 1955. Sensitivity and time of degeneration of spermatogenic cells irradiated at various stages of maturation in the mouse. Radiation Research, 2, 369-391.

OAKBERG, E. F. 1957. Duration of spermatogenesis in the mouse and timing of stages of the cycle of the seminiferous epithelium. Amer. F. Anat. (in the press).

RUSSELL, W. L., RUSSELL, L. B., AND Kimball, A. W. 1954. The relative effectiveness of neutrons from a nuclear detonation and from a cyclotron in inducing dominant lethals in the mouse. Amer. Nat., 88, 269-286.

SCHAEFER, H. 1939. Die Fertilität von Mäusermännchen nach Bestrahlung mit 2oor. Z.f. mikro-anat. Forsch., $46,121-152$.

SIRLIN, J. L., AND EDWARDS, R. G. 1955. The labelling of mouse sperm by adenine8-C-1 4. Exp. Cell Res., 9, 596-599.

SIRLIN, J. L., AND EDWARDS, R. G. 1957. Sensitivity of immature mouse sperm to the mutagenic effects of X-rays. Nature, 179, 725-727.

SNELl, G. D. 1933. X-ray sterility in the male house mouse. 7. Exptl. Zool., 65, $42 \mathrm{I}-44 \mathrm{I}$.

SPARROW, A. H. I95I. Radiation sensitivity of cells during mitotic and meiotic cycles, with emphasis on possible cytochemical changes. Ann. N.Y. Acad. Sci., 5I, 1 508-1540. 